\title{
GENRE, IDEOLOGY, AND KNOWLEDGE IN ACADEMIC RESEARCH AND PUBLIC POLICY
}

\author{
Tosh Tachino*
}

Abstract: In the last 30 years genre scholars have explored the ideological dimension of genre, illustrating how genres compel individuals to act in certain ways and how individuals respond to them. This article takes the ideological view of genre and analyzes the problem of knowledge mobilization as an ideological negotiation between research and legal genres. Using Foucault's will to truth and Bhatia's colonization, this case study analyzes one Canadian public inquiry that used psychology research and influenced many legal and policy documents. The analysis of the commission report, transcripts from the preliminary bearing, and interviews reveal the manner in which judicial ideology is inscribed in judicial genres that regulate the extent and manner of knowledge mobilization.

Keywords: Genre. Ideology. Colonization.

\section{INTRODUCTION}

Genre scholars have long noted that genre is ideological (DEVITT, 2004; FREEDMAN, 1996; MILLER, 1984), and a number of researchers in the last twenty years have amply demonstrated the ways in which genres compel individuals to act in certain ways (PARÉ, 1993, 2002; SEGAL, 1993) and, to a lesser extent, the ways in which individuals respond to ideology embedded in genres (ARTEMEVA, 2007). More recently, however, genre scholars have turned to investigate the nature of interactions among multiple genres (BHATIA, 2002; BAZERMAN, 1994; DEVITT, 1991, 2004; SPINUZZI, 2004), and subsequently, issues in genre and ideology are no longer limited to the ones that take place within a single genre but how ideology is negotiated at the intersection of multiple genres (ARTEMEVA; FREEDMAN, 2001).

One such intersection is the crossroads among (social) science research, law, and public policy, in which knowledge mobilization from (social) science research is simultaneously encouraged (JASANOFF,

\footnotetext{
*University of Winnipeg, Manitoba, Canada. Email: t.tachino@uwinnipeg.ca.
} 
2005) and contested (PRIVEN, 2001) by policy makers and courts. Analyzing this problem of knowledge mobilization as an ideological issue is not new, as many political scientists have done so (CARDEN, 2005; CAPLAN, 1979). However, these analyses typically do not emphasize the role of discourse or genre; even when they do mention language (e.g., COURT; HOVLAND; YOUNG, 2005), these analyses take structuralist views on language, and their analyses do not reflect the rhetorical approach that genre scholars often take for granted. For these reasons, analyzing the problem of knowledge mobilization from the perspective of genre theory adds to the existing interdisciplinary endeavor. At the same time, such analysis reveals the ways in which ideology is negotiated at the intersections of genres from multiple domains.

In order to achieve these objectives, this article provides a case study from one Canadian public inquiry that illustrates the ideological and discursive negotiations between scholarly genres and judicial genres. These negotiations reveal the complex process of knowledge mobilization and the role of language in this process.

\section{KNOWLEDGE MOBILIZATION}

Political scientists who studied knowledge mobilization rejected the idea that the process is a direct application of research to policy (CAPLAN, 1979). Rather, they understood the role of research as "enlightenment" (WEISS, 1979), interacting with other elements in a particular context (CARDEN, 2005, JASANOFF, 2005; KINGDON, 1984). Science and law have a number of fundamental (but legitimate) differences that make it difficult to understand one another. These differences include: the overall systemic approach, the verification method, repeatability of the "experiment," the criteria, the conceptualization of "truth," the source of data (findings), the role of social factors, and the power relationship (BERTIN; HENIFIN, 1994; JASANOFF, 1995; MATSON, 1999; NATIONAL RESEARCH COUNCIL, 2002; SHAPIRO, 1981) (see Figure 1). 


\begin{tabular}{|c|c|c|}
\hline & Science & Law \\
\hline System & Consensus seeking & Adversarial \\
\hline Verification & Replication, Peer-review & Cross-examination \\
\hline Repeatability & $\begin{array}{l}\text { Experiments are repeatable } \\
\text { (thus will happen in the } \\
\text { future) }\end{array}$ & $\begin{array}{l}\text { Theories to be proved in } \\
\text { the court occurred in the } \\
\text { past and unrepeatable }\end{array}$ \\
\hline Criteria & $\begin{array}{l}\text { alpha level, depending on the } \\
\text { discipline (e.g. .05 for social } \\
\text { sciences; } .001 \text { for medical) }\end{array}$ & $\begin{array}{l}\text { "beyond reasonable doubt" } \\
\text { "likelier than not" }\end{array}$ \\
\hline Truth & Tentative and mutable & $\begin{array}{l}\text { Must be final in a short } \\
\text { time (for the purpose of } \\
\text { resolving a dispute) }\end{array}$ \\
\hline Findings & $\begin{array}{l}\text { Forward-looking (assumes } \\
\text { tentativeness of the present } \\
\text { "truth") }\end{array}$ & $\begin{array}{l}\text { Backward-looking (rely on } \\
\text { precedents for "truth") }\end{array}$ \\
\hline $\begin{array}{l}\text { Social } \\
\text { Factors }\end{array}$ & $\begin{array}{l}\text { (in natural science) social } \\
\text { factors and social justice as } \\
\text { largely irrelevant. }\end{array}$ & $\begin{array}{l}\text { Social factors and social } \\
\text { justice as integral to the } \\
\text { decision making process. }\end{array}$ \\
\hline Power & $\begin{array}{l}\text { Experts are in charge of the } \\
\text { dialogue (and they are } \\
\text { roughly equal) }\end{array}$ & $\begin{array}{l}\text { Dialogues are controlled } \\
\text { by the judge and the } \\
\text { lawyers (not by the } \\
\text { experts) }\end{array}$ \\
\hline
\end{tabular}

Figure 1 - Some critical differences between science and law

The court's struggle to strike the right balance is highlighted in several cases in the twentieth century. Through Frye $v$. United States in 1923, the American judicial system established that an expert is admitted only if s/he meets the "general acceptance" principle. This rule has been expanded through Daubert v. Merrell Dow Pharmaceuticals in 1993, which added the following three admissibility criteria:

1. the testimony is based upon sufficient facts or data

2. the testimony is the product of reliable principles and methods

3. the witness has applied the principles and methods reliably to the facts of the case. (Federal Rules of Evidence, Rule 702) 
While critics (e.g. BERTIN; HENIFIN, 1994) questioned the trial judge's ability to evaluate (social) scientific methods, judicial authority was reinforced and extended through General Electric Co. v. Joiner and Kumbo Tire Co. Ltd. v. Carmichael.

The admissibility standard in Canada has been historically somewhat different from the U.S., but Glancy and Bradford (2007) argue that the Canadian standard is becoming much closer to the Daubert rules through recent decisions.

Prior to 1994, the Canadian admissibility standard was rather lax, admitting most experts as long as they were "helpful." But through $\mathrm{R} v$. Mohan in 1994, the court established that the admissibility standards were to be based on 1) relevance, 2) necessity, 3) absence of exculpatory rule, and 4) proper qualification. Perhaps the most important Canadian case occurred in 2000 when Judge Binnie explicitly referred to the Mohan criteria as outdated and appealed to the Daubert criteria as the test of reliability in admitting experts.

\section{DISCOURSE, IDEOLOGY, AND GENRE}

Just as much as ideology is relevant to political science and law, language scholars have explored the connection between language and ideology (e.g. BHATIA, 2002; DEVITT, 2004; DIJK, 2001; HUCKIN, 2002; WODAK, 1995). Many of these scholars use the concepts from theories of hegemony (e.g., GRAMSCI, 1971; LACLAU; MOUFFE, 1985 as cited in FAIRCLOUGH, 1992) and identify language as a manifestation of or a tool for "opaque as well as transparent structural relationships of dominance, discrimination, power and control" (WODAK, 2004, p. 204). These assumptions of language are applied to the problem of knowledge in Foucault (1972a, 1972b), who attempted to explain the creation and maintenance of knowledge through shifts in epistemic authority, will to truth, and rules of exclusion.

To explain the creation of "truth," Foucault (1972a) notes a particular shift in authority from the author of a statement to the statement itself. He illustrates this point with Greek poets, who determined truthfulness of the statements by the credibility of the speakers and the manner of their speaking. Yet, the truthfulness, which 
had derived from the speaker, was later ascribed to the internal property of the statement itself. This process of separating and obscuring the source of authority is further developed with the sixteenth and seventeenth century English scientists, who rhetorically constructed measurements, classification schemata, particular viewpoints, and terminologies (e.g. "look rather than read, verify rather than comment" [p. 218]) to satisfy their will to knowledge. This will to knowledge and the will to truth populate the discursive formation of science to hide the rhetoricity from the system:

True discourse, liberated by the nature of its form from desire and power, is incapable of recognising the will to truth which pervades it; and the will to truth, having imposed itself upon us for so long, is such that the truth it seeks to reveal cannot fail to mask it (p. 219).

If knowledge-making is discursive, so is creation and maintenance of power, and Foucault (1972b) points out the ideological nature of scientific knowledge. Using "madness" as an example, Foucault contrasts the discursive formations of medical knowledge in the classical time and that of psychopathology in the nineteenth century to point out that scientific discourse in nineteenth century psychopathology was a localized discursive formation within larger discursive formations. According to Foucault (1972a), power is accrued in this theoretical framework by this discursive relationship and the rules of exclusions that regulate what can be spoken of, where and how it can be spoken, and who is authorized to speak of it (p. 216). His example comes from Mendel, whose work on heredity was unappreciated by the early nineteenth century botanist. Foucault argues that these rules of exclusion prohibited Mendel from participating in the discursive formations because Mendel discussed his work using theories and terminologies that were not part of the discipline of botany in his time.

Another important analytical framework is Bhatia's (2002) theory of genre colony and the concept of colonization. The former refers to a collection of genres that are characterized by a general communicative purpose, such as promotion, introduction, and reporting. Because these 
purposes are general, genres that belong to each colony cut across the traditional disciplinary and professional boundaries. But what is important here is the process of colonization, which:

[...] involves invasion of the integrity of one genre by another genre or genre convention, often leading to the creation of a hybrid form, which eventually shares some of its genre characteristics with the one that influenced it in the first place (p. $58)$.

Bhatia illustrates this colonization process through the advertising genre, which clearly invaded the territorial integrity of many genres, such as academic, corporate, political, journalistic, and other genres. As a result, many of these genres now contain a wide variety of rhetorical and linguistic elements borrowed from the advertising genre, expanding the territory of the promotional genre colony.

As this case study will show, these concepts allow us to recognize the ideological nature of language and genre and to analyze the ideological and discursive negotiations that take place between (social) science and law.

\section{METHOD}

In order to examine the ways in which ideology is negotiated at an intersection of genres and how that interaction affects knowledge mobilization, this study examines one Canadian public inquiry, known as the Sophonow Inquiry. This case was chosen because it exemplifies a successful instance of knowledge mobilization and it clearly involved multiple genres from different domains.

\subsection{The Sophonow Inquiry}

The Sophonow Inquiry is a public inquiry in response to the wrongful conviction and incarceration of Thomas Sophonow from Winnipeg, who spent four years in prison. A public inquiry is a government-initiated review that establishes facts and causes of an event 
of some public significance and makes recommendations to the government. The process is similar to a court proceeding in that the commissioner, acting like a judge, summons witnesses to a preliminary hearing, who undergo direct and cross examinations by counsels that represent all stakeholders. Through the preliminary hearing, the commissioner produces a report that typically includes recommendations that call for specific policy changes. While commissions are not required to use research data, it is not uncommon for the commissions to do so. Similarly, the recommendations are not binding, but it is not uncommon for the government to follow these recommendations.

The ostensive mission of the Sophonow Inquiry was particular, but the Sophonow Inquiry was one of a series of public inquiries in Canada (e.g., the Marshall Inquiry, the Morin Inquiry) that contributed to a change in the Canadian judicial system to incorporate research findings in psychology from the 1970s and 80s, thus particularly appropriate for the current case study.

\subsection{Data}

The materials in this case study include: the commission report, the transcript from the preliminary hearing, interviews with the commissioner, the lead counsel, and two of the expert witnesses. The interview with the commissioner included a discourse-based interview to see what explanations (if any) he would provide for his rhetorical choices in writing the commission report.

\section{RESULTS AND DISCUSSION}

As predicted from the literature, participants in this study articulated a nuanced argument about the role of experts in judicial genres. Both the commissioner and the lead counsel noted the ways in which experts can serve the judicial system, but their wording made it clear that the experts should not take the center stage. In the lead counsel's words: 
I think there's a role for experts, but I think we have to be careful that experts don't dominate the courtroom. It ought not to be a battle of experts. The ultimate decision ought to be left at the judge, but the law in Canada on expert evidence is that beyond the expertise of the prospective juror, then and it's not junk science, then the experts should be allowed to offer opinions.

The statements from the participants suggest that there is a mechanism to maintain this judicial control while selectively allowing knowledge mobilization from academic genres. As the following analysis shows, judicial genres contain features that both limit and facilitate knowledge mobilization from academic genres. Furthermore, the judicial ideology governs these genres in such a way to obscure this knowledge mobilization process.

\subsection{Limiting knowledge mobilization}

One obvious way in which judicial genres restrict the influence of academic genre is the rules and procedures. This genre (including the specific document that governs this specific public inquiry) reflects the judicial development in the last 20 years (e.g., The Supreme Court trilogy) to strengthen the role of the commissioner in interpreting the relevant admissibility rules. This genre, then, affords the discretionary power to the commissioner in selecting which experts are admissible and which ones are not.

The rules and procedures also explicitly govern conversation "turns" in the preliminary hearing, thus, serving as what Giltrow (2002) calls a meta-genre. Next to the commissioner, counsels occupy a more powerful discursive position, relative to the testifying experts because they are formally given their turns, and they occupy the discursive role of questioners. This role is easily inferred through grammatical modes, as most interrogatives in the transcripts are used by counsels. Furthermore, each turn by a counsel is labeled as "Q" in the transcript to signify his or her de jure and de facto role, as illustrated in the following interchange. 
(1)

Q Just to follow up on what you said in answer to Mr. Commissioner's question, Dr. O’Shaughnessy, Dr. Sheilah Martin, a Compensation Expert, gave evidence to the Commission yesterday and the day before about the distinction in her mind between a single event trauma, a single intrusive experience on the one hand, and a process of harm that is continually inflicted on a daily basis, on the other hand. I take it that is what you have just been talking about?

A Yeah, basically. I mean, not from a compensation perspective, obviously, but, yeah, there are significant psychiatric differences.

Q Yes. Yes. Now, you describe some of the symptoms that he has exhibited over the years as quite disturbing. Those words appear at the last complete paragraph at the first sentence of the last paragraph on page six.

A Yes

(p. 1600-1601)

In addition to these explicitly documented advantages, counsels have additional advantage over experts through their genre competence. Lawyers use various discourse strategies to control the utterances of the experts, who are often less competent in this genre (GIBBONS, 2003; MATSON, 1999; SHUY, 2006). Such discourse strategies are quite obvious in the discourse data from this preliminary hearing:

(2a) All right. Because that case doesn't really stand for the proposition that wrongful incarceration would necessarily breach Section 7 of the Charter all by itself, does it? (p. 1441)

(2b) Is it fair to categorize these together as fear of revictimization? (p. 1783)

(2c) In your view, if a trial judge alerted a jury to some of the failings of the type of evidence that you have commented on here, the photo pack and some of the eyewitnesses as to potential, I use the word tainting, or exposure to things that might adversely affect their recollection; if a trial judge is 
relatively careful in alerting the jury to the potential of that recollection not being accurate because of those facts, do you say that that is sufficient education of the jury? (p. 9046)

(2a) is an example of a tag question, and (2b) is an example of a formulaic expression ("Is it fair...?") that paraphrases the expert testimony in a particular manner. (2c) is an example of a hypothetical question. Like many hypothetical questions in the courtroom, this question is not hypothetical at all but is presented hypothetically to elicit particular answers from the witness. When the expert answered this question by rejecting some of the premises in the question, it was quickly revealed that the question was not hypothetical at all, and the expert could not reject the premises because they had already happened in the Sophonow case. (2d)

Perhaps as a result of these discursive strategies, there was a systematic imbalance in the average length per turn between counsels and testifying experts. Overall the average length per turn was approximately the same between counsels and experts, but experts' turns were a mix of very short and very long answers whereas counsels' turns typically fell between these two extremes. Experts' long turns reflect their expert knowledge, which sometimes required long turns to present their complex analyses, but it is their short turns and the counsels' relatively lengthy questions that reveal the counsels' discursive strategies.

In fact, a significant number of expert turns were short responses, containing one or few words (e.g. "Yes." "That's correct." "He did." "That's right." "Indeed.") with optional restatements of the questions. These short turns constituted 1227 of 2368 expert turns (51.8\%), indicating the prevalence of interchanges like (1), consistent with the literature on legal discourses (e.g. GIBBONS, 2003; SHUY, 2006) as well as manuals for lawyers, which teach them to control and domesticate expert responses.

These discursive moves, along with the discursive context, are what make the preliminary hearing a discursive gatekeeper of the legal community. These discursive moves also make it possible for the legal community to impose its own will onto other discourses. Therefore, any utterances that are produced under this condition should be seen as a 
legal discourse even though the utterances may contain discursive features of non-legal genres.

\subsection{Facilitating knowledge mobilization}

Even under such constraints, experts appear to have meaningful influence, but the influence appears to occur because of these legal constraints, not despite them. As the analysis in this section shows, the influence of research and academic genres seldom comes from scholarly journals but mostly from the experts' re-articulations of them in the preliminary hearing. The first pair ( $3 \mathrm{a}$ and $3 \mathrm{~b}$ ) illustrates the differences in the influence of academic genre and also differences in language between a research article and the commission report.

(3a) [Research Article] The average estimate of duration across 66 subjects was $147.3 \mathrm{~s}$, which confirms earlier findings of time overestimation for complex events. Only two (3 per cent) subjects estimated a duration that was equal to or less than the true value of $30 \mathrm{~s}$ (p. 5)

(3b) [Commission Report] Interestingly, witnesses almost always think that an event took place over a longer period of time than it actually did. (p. 27)

All three sentences in (3a) and (3b) are syntactically identical in that each sentence is complex with one subordinate clause, but (3a) morphologically contains greater nominalizations (e.g. estimate, duration, overestimation). Rhetorically (3a) emphasizes precision through presentation of quantitative data, and it maintains a more hesitant stance toward generalization by preserving the source of knowledge.

By comparison (3b), which could be nominalized as "witness" overestimation of an event," does not resort to nominalization, and the sentence is rhetorically constructed to present the information as a generalizable fact. This rhetorical generalization is partly achieved by obscuring the source and the process of the knowledge, which makes it more difficult for the reader to contest it. 
While the comparison of language between research articles and the commission report yields few similarities, a comparison between the transcript of the preliminary hearing and the commission report yields more obvious connections. The paired excerpt in (4) comes from sections in the preliminary hearing and the commission report that explain the basic model of how memory functions.

(4a) [Transcript] So the first stage is the acquisition stage. This is a period of time where an event occurs and some information is laid down in the memory system. And then when the event is over, time passes. We call this stage the retention stage. And finally there's a period of time, another stage that we call the retrieval stage. This is when a person tries to retrieve information from memory to answer questions about what happened, to look at photographs and try to make an identification. These are all different acts of retrieval. Our job then as researchers in this area is to identify the factors that come into play at each of these stages that affect the accuracy of somebody's memory (p. 89228923).

(4b) [Commission Report] The acquisition phase represents the time when an event occurs and some information is stored in the memory system. After the event is over, time passes and this period is referred to as the retention stage. Finally, there is the retrieval stage. This occurs when a person attempts to retrieve information from the memory in response to questions as to what happened. For example, retrieval takes place when a witness is asked to look at photographs in order to try to mak

In addition to the obvious ideational repetitions, one can readily see the linguistic repetitions at the levels of lexical, phrasal, and even clausal. Just in the first few lines, we see the reiteration of: the acquisition stage (noun phrase), time (lexical item), an event occurs and some information is ... in the memory system (two clauses). Furthermore, the morphology of the original sentences, such as the grammatical subject, tense, aspect, mode, and voice, perseveres in the commission report. In both texts, the grammatical subject slots are occupied by non-human phenomenal nouns (such as the first stage, retrieval) and demonstratives that refer to 
them (e.g. this). Similarly, all verbs are in present tense, simple aspect, and all the main clauses are in indicative mode and use active voice.

While both the preliminary hearing and the commission report are both legal genres, thus falling under the same Bhatia's (2004) professional genre, these two genres are clearly different genres with their own general communicative purposes. Thus, the linguistic repetition in (4) constitutes Bhatia's colonization that invades and compromises the generic integrity of one genre by another.

This point is important because the above transcript segment is an utterance by an academic expert; therefore, the linguistic repetitions of these utterances in the commission report represent an opportunity for academic experts to potentially colonize legal genres with academic ones. This means that the worldviews and values of academic genres can potentially have an influence on the legal genres, perhaps allowing the legal professionals to see the world from the academic point of view. Of course, such colonization effort is neither simple nor easy because of all the legal constraints mentioned earlier. However, evidence suggests that such colonization is possible. The excerpt in (5) illustrates an instance in which a counsel (Q) voluntarily introduces a psychological term from another expert to make sense of the testimony of the current expert (A):

Q Yes, thank you. And the identification process utilized at any point in time is one of those I think Dr. Loftus calls it a post event factor that can shape one's memory that has been acquired and retained?

A Certainly. (p. 9959-9960)

In addition to these lexical, phrasal, clausal, and morphological repetitions, the commission report also preserves rhetorical elements, such as emphasis and qualification. The following example comes from a section in the preliminary hearing transcript, in which a law expert testifies about the goals of tort laws, followed by the commissioner's use of this testimony. 
(6a) [Transcript] And while the goals of tort are many, it's often said that the primary function of tort law is to provide first all for compensation for an injured party. . . A second goal of tort would be in the deterrence of conduct seen to be problematic or below a certain standard of expected performance. (p. 1266-1267)

(6b) [Commission Report] The primary goal of tort law is to compensate the injured party and, secondly, to act as a deterrent to misconduct (p. 93).

Ideationally, (6b) is a summary (6a). Linguistically, we see repetitions of lexemes (e.g. compensation vs. compensate, deterrence vs. deterrent) as well as other morphological elements, such as the grammatical subject, mode and voice. In addition, what perseveres in (6b) are the parts in (6a) that are given rhetorical emphasis. The first sentence of (6a) rhetorically emphasizes "the primary function of tort law is to provide..." through its syntactic position (right branch in the main clause) as well as its rhetorical position ("new" slot in the givennew contract [see KOLLN, 2007]). Because what is stated is given a greater rhetorical emphasis than what is not stated, one could argue that this pair represents a repetition of rhetorical emphasis in addition to the linguistic and ideational repetitions.

These examples may appear remarkable and exceptional in the extent to which the expert utterances are repeated, but these examples are, in fact, typical of how the commission report used expert testimony. Indeed, a similar analysis of the entire expert sections in the commission report reveals that almost every sentence is directly traceable to a specific segment in the transcript with abundant linguistic repetitions. Only 16 out of 226 sentences or approximately $7 \%$ of all the sentences did not have an obvious corresponding section in the transcript.

In addition to the linguistic and rhetorical repetitions, the commissioner's use of the transcript is also obvious at the level of organization. Ideas in the expert sections of the commission report are clearly organized in the order they appear in the transcript. To demonstrate this organizational influence, Table 2 lists the first ten sentences from the Loftus and O'Shaughnessy (two experts) sections of the commission report. The number(s) next to each sentence is (are) the 
page numbers in the transcript where the corresponding section can be found. A question mark in the transcript page indicates that the sentence is one of 16 sentences with no corresponding section in the transcript.

\begin{tabular}{|l|r|l|r|}
\hline \multicolumn{2}{|c|}{ Loftus } & \multicolumn{2}{c|}{ O'Shaughnessy } \\
\hline Cory Report & Transcript p. & Cory Report & Transcript p. \\
\hline Dr. Loftus is a full professor... & 8915 & Dr. O'Shaughnessy is... & 1574 \\
\hline Her curriculum vitae is filled... & 8914 & He is presently the... & $1576-1577$ \\
\hline She has conducted... & $8916-8917$ & Dr. O'Shaughnessy's... & $1574-1579$ \\
\hline Her 1996 report,... & 8921 & Dr. O'Shaughnessy was... & $?$ \\
\hline Since that report... & 8921 & As I started earlier... & $?$ \\
\hline She testified that memory ... & 8922 & In Dr. O'Shaughnessy's... & 1590 \\
\hline Research has been... & 8923 & He testified that... & 1591 \\
\hline The acquisition phase... & 8923 & He is totally preoccupied... & 1592 \\
\hline After the event is... & 8923 & He has experienced... & 1592 \\
\hline Finally, there is ... & 8923 & He has an obsessional... & 1593 \\
\hline
\end{tabular}

Figure 2 - Cross-referencing Cory Report and Transcript

The figure clearly shows a corresponding progression between the commission report and the transcript, indicating that the organization in the preliminary hearing contributed to the organization of the commission report. But this prevalence of the linguistic and rhetorical uptake does not lead us to the conclusion that academic researchers have direct influence on policy recommendations. These expert utterances are already partially shaped by the explicit and implicit rules of the legal community, the form and content of the question, and the mediation by the oral genre of the preliminary hearing. Furthermore, not all expert utterances were repeated, and it was at the commissioner's discretion to decide which expert utterances were ultimately repeated and how these utterances were framed, sequenced, and judged in the final report.

In short, the commission report is both ideationally and linguistically influenced by research, but this influence is made possible by "recreating" the academic content and language in the legal genre of preliminary hearing. 


\subsection{Will to truth}

As discussed in the previous sections, counsels made various discourse moves to emphasize judicial and policy genres and to encourage expert witnesses to "recreate" research knowledge within the judicial genre of preliminary hearing. Subsequently, the commissioner's attribution of research knowledge is mostly to the preliminary hearing, the transcript of the preliminary hearing, or the researchers as expert witnesses ( $85 \%$ of all the attributed research knowledge in the report); considerably less attribution to other sources are found (15\% to written research genres but other knowledge claims are unattributed.)

Superficially, there is nothing interesting about the commissioner's attribution practice. The terms of reference for this commission specifically designated the preliminary hearing as the fact finding venue, so the commissioner was simply observing this legal obligation to gather and generate knowledge from the preliminary hearing and attributing to it. Yet many sources were brought into the preliminary hearing, filed as evidence, and influenced the commission's final recommendations, and it is rather curious to note the absence of these sources from the commission report. The most conspicuous example is the Eyewitness Evidence, a practical guide for law enforcement, published by the National Institute of Justice. This booklet contains practical advice grounded in psychology research, and this source (filed as evidence in the preliminary hearing) appears very influential in some of the recommendations in the commission report:

(7a) [Eyewitness Evidence] Instruct the witness that the person who committed the crime may or may not be present in the group of individuals (p. 32).

(7b) [Commission Report] The officer should emphasize to the witness that the suspect may not be in the line-up (p. 31, emphasis in original).

(8a) [Eye Witness Evidence] Select fillers who generally fit the witness' description of the perpetrator. When there is a limited/inadequate description of the perpetrator provided by the witness, or when the description of the perpetrator differs 
significantly from the appearance of the suspect, fillers should resemble the suspect in significant features (p. 30).

(8b) [Commission report] The filler in the line-up should match as closely as possible the descriptions given by the eyewitnesses at the time of the event. It is only if that is impossible, that the fillers should resemble the suspect as closely as possible (p. 31, emphasis in original.).

Yet, the Eyewitness Evidence is never mentioned in the commission report, and the commissioner's explanation of this absence is rather curious.

Researcher: Quite a few of the recommendations in this section ((pointing to p. 31-34 in the Cory report, recommendation section on eyewitnesses)) seem to come from Eyewitness Testimony ((showing him the cover of the document and presenting it to him)). My first question is: How important is this document?

Commissioner: No! This is just part of the background! Part of the background! Part of the (matrix) you gather your recommendations from all the evidence that you have considered and accepted, and to say that dominates? No. You have to all sort the evidence of Elizabeth Loftus, evidence of the other chap that has an international reputation on eyewitness ()

Researcher: Yes

Commissioner: And, generally, it's always the sum total of the evidence that leads you to the conclusion. ( ) and the sum is always greater than the parts.

Notes transcription conventions

$(())$ : transcriber's description

(): inaudible

(word): dubious hearing 
A superficial interpretation of the commissioner's utterance is problematic. In light of the discourse data, it seems unlikely that all testimonies were given equal weight as they disappeared in the background, and such explanation reveals nothing about the process of decision making. Finally, the commissioner's comment suggests idealized neutrality, objectivity, and independence, which many of us (informed by postmodern theories) find rather difficult to accept. Given these problems, it may be tempting to dismiss the commissioner's response as a result of "bias, poor recall and poor or inaccurate articulation" (YIN, 2003 , p. 92). After all, the inquiry took place seven years ago, and interviewees (including the commissioner) frankly admitted problems of recalling specifics.

Yet, the commissioner's unwillingness to discuss an obviously important source suggests that Foucault's will to truth may be at play. In order to analyze the commissioner's interview data, it is perhaps useful to remind ourselves what methodologists say about interview data. Far from being an objective description of reality, interview data should be viewed as an account that has been "filtered and modified by his cognitive and emotional reactions and reported through his personal verbal usage" (DEAN; WHYTE, 1970, p. 120, emphasis in original). Given this characterization of interview data and Foucault's discursive formation, we should treat interviews as eliciting a socially and discursively constructed framework of a participant and the objects that are filtered through that framework.

This Foucauldian view allows us to recognize the commissioner's stake in the legal system. As described earlier, a commissioner is legally and discursively constructed as a judge, and, thus, he is expected to fulfill responsibilities that are ordinarily associated with a judge, such as neutrality, objectivity, and independence. It is through this formally assigned role that the commissioner's recommendations are received and accepted as valid.

Therefore, it misses the point if we dismiss those idealized qualities of a judge on the ground that these qualities are literally impossible in our framework, our own disciplinary discursive formations, and our rules of exclusion. Rather, we need to examine how the legal discursive formations enable the possibility of these qualities, and how 
Commissioner Cory rhetorically possesses those qualities. In doing so, we must separate Cory's role from the individual who occupies this position: The flesh-and-blood Cory may not be immune to biases and prior knowledge, like every other human being, but these human qualities are masked by the legal will to truth, and Cory-theCommissioner must be and is construed as neutral, objective, and independent.

This assumption is crucial to the working of the legal system because admitting a lack of these idealized qualities would invalidate his recommendations, just as much as lack neutrality of a trial judge is grounds for overturning a verdict. Under this condition the commissioner could not afford to speak outside this discursive formation; as a representative of this system, he must propagate the validity of this will to truth.

This explanation is supported by several other segments of the interview, in which the commissioner consistently rejected the idea of any prior knowledge or opinions. ("You wouldn't be a useful commissioner if you had made up your mind.") Similarly, his description of his decision making process de-emphasized any specific connections and influences from individual sources

The discourse and interview data suggest that the judicial system inscribes its ideology in their genres to ensure judicial authority and independence, but this existing mechanism already allows knowledge mobilization (both at the level of content and language). However, the influence must be negotiated and "recreated" within a legal genre (preliminary hearing in this case) before it is effective. As a result, the influence may be made invisible through Foucault's will to truth, and as we saw in the last analysis section, direct questioning through an interview may not unmask the hidden process.

These findings suggest that (social) scientific experts may be able to contribute to knowledge mobilization by recreating the content and language of their research. In addition, careful phrasing of oral testimony can lead to Bhatia's colonization of legal genres. At the same time, the analysis illustrates some limitations of interviewing, suggesting that language analysis should be an important component in understanding knowledge mobilization. 


\section{CONCLUSION}

This case study has revealed the ways in which judicial ideology is implicated in judicial genres: These genres perform the dual function of limiting and facilitating knowledge mobilization while obscuring the means of performing this dual function. The legal ideology, then, allows knowledge mobilization but this is made possible not by confronting the ideology. Rather, this case study suggests that academic researchers have a better chance of achieving knowledge mobilization by working within the constraints of the judicial ideology and genres, "recreating" enough (but not too much) content and form from academic genres for the influence to be meaningful. Of course, generalizability of these findings is limited by the fact that the current study is a case study. But the analysis illustrates the ways in which genre scholars can contribute to the scholarly inquiry of knowledge mobilization. At the same time, genre researchers are encouraged to examine similar cases to see if these patterns may be found in other cases in order to address the inherent limitation of a single case study.

\section{REFERENCES}

ARTEMEVA, N. Approaches to learning genres: A bibliographical essay. In: ARTEMEVA, N.; FREEDMAN, A. Rhetorical genre studies and beyond. Winnipeg, Manitoba, Canada: Inkshed, 2007. p. 9-99.

ARTEMEVA, N.; FREEDMAN, A. Just the boys playing on computers: an activity theory analysis of differences in the cultures of two engineering firms. Journal of Business and Technical Communication, Thousand Oaks, CA, v. 15, n. 2, p. 164-194, 2001.

BAZERMAN, C. Systems of genres and the enactment of social intentions. In: FREEDMAN, A.; MEDWAY, P. Genre and the new rhetoric. London: Taylor \& Francis, 1994, p. 79-101.

BERTIN, J. E.; HENIFIN, M. S. Science, law, and the search for truth in the courtroom: Lessons from Daubert v. Merril Dow. Journal of Law, Medicine \& Ethics, Boston, v. 22, n. 1, p. 6-19, 1994.

BHATIA, V. K. Worlds of written discourse. London: Continuum, 2004. 
CAPLAN, N. The two-communities theory and knowledge utilization. American Behavioral Scientist, Thousand Oaks, CA, v. 22, n. 3, p. 459-470, 1979.

CARDEN, F. Making the most of research: The influence of IDRCsupported research on policy processes. Paper presented at the International conference African Economic Research Institutions and Policy Development: Opportunities and Challenges. Dakar, Senegal, 2005. Available at: $<<$ http://web.idrc.ca/uploads/user-S/ 11085518871Making_the_Most_of_Research.pdf $>>$

COURT, J.; HOVLAND, I.; YOUNG, J. Bringing research and policy in development: evidence and the change process. Warwickshire, England: ITDG, 2005.

DEAN , J. p. ; WHY'TE, W. F. What kind of truth do you get? "How do you know if the informant is telling the truth?" In: DEXTER, L. A. Elite and specialized interviewing. Evanston, IL: Northwestern University Press, 1970. p. 119-138.

DEVIT'T, A. J. Intertextuality in tax accounting: Generic, referential, and functional. In: BAZERMAN, C.; PARADIS, J. Textual dynamics of the profession: Historical and contemporary studies of writing in professional communities. Madison: University of Wisconsin Press, 1991. p. 335-357.

Writing genres. Carbondale: Southern Illinois University Press, 2004.

DIJK, T. A. van. Critical discourse analysis. In: SCHIFFRIN, D.; TANNEN, D.; HAMILTON, H. E. The handbook of discourse analysis. Malden, MA: Blackwell, 2001. p. 352-371.

FEDERAL Rules of Evidence Act, 28 U.S.C. \ 2074, 1975.

FAIRCLOUGH, N. Discourse and social change. Cambridge, England: Polity Press, 1992.

FOUCAULT, M. The discourse on language. In: SMITH, A. M. (Trans.). The archaeology of knowledge. New York: Pantheon Books, 1972a. p. 215-237. The archaeology of knowledge. In: SMITH, A. M. (Trans.). The archaeology of knowledge New York: Pantheon Books, $1972 \mathrm{~b}$.

FREEDMAN. A. Genres of argument and arguments as genres. In: BERRILL, D. P. Perspectives on written argument. Creskill, NJ: Hampton Press, 1996. p. $91-120$. 
GIBBONS, J. Forensic linguistics: an introduction to language in the justice system. Malden, MA: Blackwell, 2003.

GILTROW, J. Meta-genre. In: COE, R.; LINGARD, L.; TESLENKO, T. The rhetoric and ideology of genre. Creskill, NJ: Hampton, 2002, p. 187-205.

GLANCY, G. D.; BRADFORD, J. M. W. The admissibility of expert evidence in Canada. Journal of American Academy of Psychiatry and the Law, Stanford, CA, v. 35, n. 3, p. 350-356, 2007.

GOLAN, T. Laws of men and laws of nature: the history of scientific expert testimony in England and America. Cambridge, MA: Harvard University, 2004.

HUCKIN, T. Critical discourse analysis and the discourse of condescension. In: BARTON, E.; STYGALL, G. Discourse studies in composition. Cresskill, NJ: Hampton, 2002. p. 155-176.

JASANOFF, S. Science at the bar: Law, science, and technology in America. Cambridge, MA: Harvard University, 1995.

Designs on nature: Science and democracy in Europe and the United States. Princeton, NJ: Princeton University, 2005.

KINGDON, J. Agendas, alternatives and public policies. Boston: Little Brown, 1984.

KOLLN, M. Rhetorical grammar: Grammatical choices, rhetorical effects. 5 ed. New York: Pearson Education, 2007.

MATSON, J. V. Effective expert witnessing. 3. ed. Boca Raton, FL: CRC, 1999.

MILLER, C. R. Genre as social action. Quarterly Journal of Speech, London, v. 70, n. 2, p. 151-167, 1984.

NATIONAL RESEARCH COUNCIL. The age of expert testimony: Science in the courtroom: Report of a workshop. Washington, DC: National Academy, 2002.

PARÉ, A. Discourse regulations and the production of knowledge. In: SPILKA, R. Writing in the workplace: New research perspectives. Carbondale: Southern Illinois University, 1993. p. 111-123.

. Genre and identity: Individuals, institutions, and ideology. In: COE, R.; LINGARD, L.; TESLENKO, T. The rhetoric and ideology of genre. Creskill, NJ: Hampton, 2002. p. 57-71. 
PRIVEN, F. F. The politics of policy science. In: SHAPIRO, I.; SMITH, R.; SASOUD, T. Problems and method in the study of politics. Cambridge, England: Cambridge University, 2004, p. 83-105.

SEGAL, J. Writing and medicine: Text and context. In: SPILKA, R.: Writing in the workplace: New research perspectives. Carbondale: Southern Illinois University, 1993. p. 84-97.

SHAPIRO, M. Courts: a comparative and political analysis. Chicago: University of Chicago, 1981.

SHUY, R. W. Linguistics in the courtroom: a practical guide. New York: New York University, 2006.

SPINUZZI, C. Four ways to investigate assemblages of texts: Genre sets, systems, repertoires, and ecologies. In: ACM SIGDOC, New York, 2004. Available at: <<http://portal.acm.org/citation.cfm?id=1026560\#>>

WEISS, C. H. Research for policy's sake: the enlightenment function of social research. Policy Analysis, Berkley, CA, v. 3, n. 4, p. 531-547, 1977.

WODAK, R. Critical linguistics and critical discourse analysis. In: VERSHUREN, J.; ÖSTMAN, J. O.; BLOMMAERT, J. Handbook of pragmatics manual. Amsterdam: J. Benjamins, 1995. p. 204-210.

YIN, R. K. Case study research: Design and methods. 3. ed. Thousand Oaks, CA: Sage, 2003.

Recebido em 30/08/2010. Aprovado em: 20/12/2010.

Título: Gênero, ideologia e conhecimento na pesquisa acadêmica e nas políticas públicas Autor: Tosh Tachino

Resumo: Nos últimos 30 anos os estudiosos de gênero têm explorado a dimensão ideológica do gênero, ilustrando como os gêneros compelem os individuos a agir de determinada maneira, e como os individuos respondem a eles. O presente artigo enfoca a visão ideológica de gênero e analisa o problema da mobilização do conhecimento como uma negociação ideológica entre gêneros legais e de pesquisa. Usando a vontade de verdade de Foucault e a colonização de Bhatia, este estudo de caso analisa um questionário público canadense que usou pesquisa em psicologia e influenciou vários documentos legais e de políticas públicas. A análise da comissão relatora, transcrições de audiências preliminares, e entrevistas revelam a maneira como a ideologia jurídica esta inscrita nos gêneros jurídicos que regulam a extensão e o modo como se dá a mobilização do conhecimento.

Palavras-chave: Gênero. Ideologia. Coloniz̧ação. 
Título: Género, ideología y conocimiento en la investigación académica y en las políticas públicas Autor: Tosh Tachino

Resumen: En los últimos 30 años los estudiosos de género han explorado la dimensión ideológica del género, ilustrando como los géneros impelen a los individuos a actuar de determinada manera, y como los individuos responden a ellos. El presente artículo enfoca la visión ideológica de género y analiza el problema de la mobilización del conocimiento como una negociación ideológica entre géneros legales y de investigación. Usando la voluntad de verdad de Foucault y la colonización de Bhatia, este estudio de caso analiza un cuestionario público canadiense que usó investigación en sicología e influenció varios documentos legales y de políticas públicas. El análisis de la comisión relatora, transcripciones de audiencias preliminares, y entrevistas revelan la manera como la ideología jurídica está inscripta en los géneros jurídicos que regulan la extensión y el modo como se da la mobilización del conocimiento.

Palabras-clave: Género. Ideología. Colonización.

TACHINO - Genre, ideology, and knowledge... 